\title{
PENGARUH PERBANDINGAN TEPUNG KACANG HIJAU (Vigna radiata) DAN TERIGU TERHADAP KARAKTERISTIK BAKSO ANALOG
}

\author{
Utafiyani. ${ }^{1}$, Ni Luh Ari Yusasrini. ${ }^{2}$, I Gusti Ayu Ekawati. ${ }^{2}$ \\ ${ }^{1}$ Mahasiswa PS. Ilmu dan Teknologi Pangan, Fakultas Teknologi Pertanian, Universitas Udayana \\ ${ }^{2}$ Dosen PS. Ilmu dan Teknologi Pangan, Fakultas Teknologi Pertanian, Universitas Udayana \\ Email: utafiyani@ymail.com
}

\begin{abstract}
This aims of this research was to know the effect of comparison between green bean flour and wheat flour on characteristic of analogue meatball and to know the right comparison of green bean flour and wheat flour to produce analogue meatball with the best characteristics. The design used in this research was completely randomized design (CRD) with the comparison between green bean flour and wheat flour i.e. $(70 \mathrm{~g}$ $: 30 \mathrm{~g}),(60 \mathrm{~g}: 40 \mathrm{~g})$, (50 $\mathrm{g}: 50 \mathrm{~g}),(40 \mathrm{~g}: 60 \mathrm{~g})$, and $(30 \mathrm{~g}: 70 \mathrm{~g})$. Data were analysed by analysis of variance, followed by Duncan test. The result of this research showed that the comparison between green bean flours and wheat flour had no real effect on water content and aroma of analogue meatball, but significant effects were found on ash content, protein content, fat content, crude fiber content, texture, sensory characteristic such as color, flavour, texture, and overall acceptance of analogue meatball. The best characteristic of analogue meatball was comparison between green bean flour and wheat flour $30 \mathrm{~g}$ : $70 \mathrm{~g}$ i.e. 59.00 percent of water content, 1.34 percent of ash content, 6.88 percent of protein content, 1.77 percent of fat content, 1.77 percent of crude fiber content, level of elasticity $6.38 \mathrm{~N}$, color (liked), aroma (neutral), texture (liked) with chewy characteristics, with the taste is rather not typical of green beans and liked, and overall acceptance (liked).
\end{abstract}

Keywords: analogue meatball, green bean flour, wheat flour

\section{PENDAHULUAN}

Bakso merupakan salah satu produk yang sangat digemari dan popular di Indonesia. Bakso biasanya terbuat dari bahan utama yaitu daging yang sudah digiling halus, kemudian dilakukan pencampuran dengan bahan-bahan lainnya, dibentuk bulat, dan selanjutnya dilakukan proses perebusan (Anon., 2006). Penggunaan daging dalam produk olahan pangan seperti bakso sering menjadi masalah terutama bagi kalangan tertentu seperti kelompok vegetarian. Banyak orang yang sekarang mulai mengurangi konsumsi daging dan beralih ke makanan yang berasal dari bahan pangan nabati dengan alasan tidak boleh mengkonsumsi produk yang mengandung daging yang menyangkut kesehatan karena daging mengandung kolestrol tinggi yang dapat menyebabkan serangan jantung dan darah tinggi. Selain itu bakso daging yang umum berada dipasaran mengandung kandungan lemak cukup tinggi yaitu sebesar 6,22\% (Sari dan Widjarnako, 2015). Bakso daging ayam juga dilaporkan mengandung kadar serat yang rendah yaitu $0,26 \%$ (Kurniawan et al., 2012).

Berbagai upaya bisa dilakukan untuk mengurangi penggunaan daging pada pembuatan bakso. Salah satunya adalah melakukan diversifikasi produk bakso dengan menggantikan bahan baku daging dengan bahan baku lain yang memiliki kandungan protein yang hampir sama dengan protein daging. Bakso yang terbuat dari bahan-bahan selain daging dan biasanya berupa bahanbahan nabati disebut sebagai bakso analog 
(Novita dan Pangesti, 2014). Tahapan pembuatan bakso analog sama dengan pembuatan bakso pada umumnya. Sumber bahan pangan yang dapat digunakan dalam pembuatan bakso analog yaitu berasal dari kelompok leguminosa, salah satunya adalah kacang hijau. Kacang hijau merupakan sumber protein nabati, karena mengandung protein tinggi sebesar 24\%, memiliki kandungan lemak yang rendah yaitu sebesar $1-1,2 \%$, serta memiliki kandungan serat sebesar 4,1\%. Bahan lain yang diperlukan dalam pembuatan bakso adalah terigu. Terigu, selain mengandung pati, juga mengandung protein dalam bentuk gluten yang berperan dalam menentukan kekenyalan suatu produk (Situngkir, 2010).

Pembuatan bakso dari tepung kacang hijau memerlukan perbandingan antara tepung kacang hijau dan terigu yang tepat agar menghasilkan bakso dengan karakteristik terbaik. Hasil penelitian sejenis yang sudah pernah dilakukan menunjukkan bahwa bakso yang terbuat dari perbandingan antara 70\% kacang merah dan 30\% terigu menghasilkan karakteristik terbaik (Genisa et al, 2015). Penelitian yang serupa oleh Rakhmawati (2011) juga melaporkan bahwa penambahan tepung kecambah kacang hijau berpengaruh terhadap kadar serat kasar dimana semakin tinggi penambahan tepung kecambah kacang hijau maka nilai serat kasar bakso daging ayam broiler akan mengalami kenaikan dari 0,2 $0,5 \%$ menjadi 1,67 - 2,47\%. Penelitian ini dilakukan dengan tujuan untuk mengetahui pengaruh perbandingan tepung kacang hijau dan terigu terhadap karakteristik bakso dan untuk mengetahui perbandingan tepung kacang hijau dan terigu yang tepat sehingga dihasilkan bakso dengan karakteristik terbaik.

\section{METODE PENELITIAN}

\section{Tempat dan Waktu}

Tempat penelitian ini adalah Laboratorium Analisis Pangan, Laboratorium Pengolahan Pangan, dan Laboratorium Rekayasa Proses dan Pengendalian Mutu, Fakultas Teknologi Pertanian, Universitas Udayana. Waktu pelaksanaan penelitian bulan April - Agustus 2017.

\section{Bahan dan Alat}

Bahan-bahan yang digunakan dalam penelitian ini terdiri dari bahan utama dan bahan pendukung. Dimana bahan utama meliputi tepung kacang hijau yang terbuat dari kacang hijau varietas lokal dan terigu bogasari cakra kembar. Bahan pendukung yang digunakan meliputi tapioka, lada, bawang putih, garam, dan gula. Bahan lain yang digunakan untuk analisis kimia antara lain tablet Kjeldahl, phenolphtalin, asam borat, $\mathrm{HCl}, \mathrm{NaOH}, \mathrm{H}_{2} \mathrm{SO}_{4}$, aquades, asam sulfat, natrium hidroksida, hexan, benang wol, dan alkohol.

Alat yang digunakan antara lain, pisau, waskom, talenan, kompor, wajan, sendok, thermometer, tabung gas, loyang, plastik, wadah, blender, sarung tangan, TA.XT.Plus Texture Analyser, gelas ukur, neraca analitik, oven, cawan porselin, alumunium foil, desikator, erlenmeyer, kertas saring, pipet volume, gelas beaker, pipet tetes, water bath, 
labu ukur, tanur listrik, tabung reaksi, alat kondensor, labu Kjeldahl, labu lemak, alat soxhlet dan kertas saring.

\section{Rancangan Percobaan}

Rancangan percobaan yang digunakan dalam penelitian ini adalah Rancangan Acak Lengkap (RAL) dengan perbandingan tepung kacang hijau dan terigu yang terdiri dari 5 level, yaitu: P1 (70 g : $30 \mathrm{~g})$, P2 (60 g : $40 \mathrm{~g}$ ), P3 (50 g : $50 \mathrm{~g}$ ), P4 (40 g : $60 \mathrm{~g}$ ), dan P5 (30 g : $70 \mathrm{~g}$ ), dimana masing-masing perlakuan diulang sebanyak 3 kali sehingga diperoleh 15 unit percobaan. Data yang diperoleh kemudian dianalisis dengan sidik ragam (ANOVA) dan apabila terdapat pengaruh $(\mathrm{P}<0,05)$ antara perlakuan maka akan dilanjutkan dengan uji Duncan Multiple Range Test (DMRT) (Steel dan Torrie, 1993).

\section{Pelaksanaan Penelitian}

Formulasi dalam pembuatan bakso analog dengan menggunakan tepung kacang hijau dan terigu dapat dilihat pada Tabel 1.

Tabel 1. Formulasi Bakso Analog

\begin{tabular}{lccccc}
\hline \multicolumn{1}{c}{ Bahan } & \multicolumn{5}{c}{ Perlakuan } \\
\cline { 2 - 6 } & P1 & P2 & P3 & P4 & P5 \\
\hline Tepung kacang hijau (\%) & 70 & 60 & 50 & 40 & 30 \\
Terigu (\%) & 30 & 40 & 50 & 60 & 70 \\
Tapioka (\%) & 25 & 25 & 25 & 25 & 25 \\
Garam (\%) & 4 & 4 & 4 & 4 & 4 \\
Gula (\%) & 3 & 3 & 3 & 3 & 3 \\
Lada bubuk (\%) & 0,5 & 0,5 & 0,5 & 0,5 & 0,5 \\
Bawang putih (\%) & 2,5 & 2,5 & 2,5 & 2,5 & 2,5 \\
Air (ml) & 75 & 75 & 75 & 75 & 75 \\
\hline Suryyyyy
\end{tabular}

Sumber: Genisa et al., (2015) yang Dimodifikasi

Keterangan: presentase diatas berdasarkan total berat tepung kacang hijau dan terigu.

\section{a. Proses Pembuatan Tepung Kacang Hijau}

Proses pembuatan tepung kacang hijau yaitu dengan cara kacang hijau disortasi dan kemudian dicuci dengan air mengalir. Kemudian dikeringkan menggunakan oven pada suhu $55^{\circ} \mathrm{C}$ selama 5 jam. Biji kacang hijau yang sudah kering kemudian digiling mengunakan blender dan diayak dengan ayakan 60 mesh (Rusiani, 2016). Tepung kacang hijau dikemas di dalam plastik dalam keadaan tertutup.

\section{b. Proses Pembuatan Bakso Analog}

Proses pembuatan bakso analog dilakukan dengan cara mencampur tepung kacang hijau dan terigu terlebih dahulu sesuai dengan perlakuan, kemudian ditambahkan bahan-bahan tambahan seperti tapioka, garam, gula, bumbu (bawang putih dan lada) serta air. Kemudian semua bahan diaduk hingga rata atau homogen. Setelah menjadi adonan kemudian dibentuk menjadi bulatan (diameter $1,5 \mathrm{~cm}$ ) dengan menggunakan tangan yang kemudian langsung dimasukkan ke dalam air panas $100^{\circ} \mathrm{C}$ selama 10 menit (sampai bakso 
mengambang), kemudian diangkat dan ditiriskan.

\section{Variabel yang Diamati}

Variabel yang diamati meliputi kadar air dengan metode pengeringan (Sudarmadji et al., 1997), kadar abu dengan metode pengabuan kering (Sudarmadji et al., 1997), kadar protein dengan metode mikro-kjeldhal (Sudarmadji et al., 1997), kadar lemak dengan metode soxhlet (Sudarmadji et al., 1997), kadar serat kasar dengan metode hidrolisis asam basa (Sudarmadji et al., 1997), tingkat kekenyalan menggunakan Texture Analyzer (Kusnadi et al., 2012) dan sifat sensori dengan uji hedonik (warna, aroma, tekstur, rasa dan penerimaan keseluruhan) dan uji skoring (rasa dan tekstur) (Soekarto, 1985).

\section{HASIL DAN PEMBAHASAN}

Hasil analisis kadar protein, kadar air, kadar abu, kadar lemak, kadar karbohidrat, kadar serat kasar bakso analog, dan tingkat kekenyalan bakso analog dari perbandingan tepung kacang hijau dan terigu dapat dilihat pada Tabel 2.

\begin{tabular}{rccccc}
\hline \multirow{2}{*}{ Perlakuan (\%) } & \multicolumn{5}{c}{ Kadar $(\%)$} \\
\cline { 2 - 5 } & Air & Abu & Protein & Lemak & Serat Kasar \\
\hline P1 (70 TKH: $30 \mathrm{~T})$ & $58,57 \mathrm{a}$ & $2,34 \mathrm{a}$ & $10,37 \mathrm{a}$ & $1,82 \mathrm{ab}$ & $3,05 \mathrm{a}$ \\
P2 (60 TKH: 40 T) & $58,82 \mathrm{a}$ & $1,95 \mathrm{~b}$ & $9,26 \mathrm{~b}$ & $1,83 \mathrm{ab}$ & $2,89 \mathrm{~b}$ \\
P3 (50 TKH: 50 T) & $58,89 \mathrm{a}$ & $1,73 \mathrm{c}$ & $8,47 \mathrm{c}$ & $1,86 \mathrm{a}$ & $2,31 \mathrm{c}$ \\
P4 (40 TKH: 60 T) & $58,69 \mathrm{a}$ & $1,57 \mathrm{~d}$ & $7,60 \mathrm{~d}$ & $1,78 \mathrm{~b}$ & $2,18 \mathrm{c}$ \\
P5 (30 TKH: 70 T) & $59,00 \mathrm{a}$ & $1,34 \mathrm{e}$ & $6,88 \mathrm{~d}$ & $1,77 \mathrm{~b}$ & $1,77 \mathrm{~d}$ \\
\hline
\end{tabular}

Tabel 2. Kadar Air, Abu, Protein, Lemak, dan Serat Kasar Bakso Analog dengan Perlakuan Perbandingan Tepung Kacang Hijau dan Terigu.

Keterangan: 1. TKH : Tepung Kacang Hijau

2. $\mathrm{T}$ : Terigu

3. Huruf yang berbeda pada kolom yang sama menunjukkan perbedaan yang sangat nyata $(\mathrm{P}<0,01)$.

\section{Kadar Air}

Hasil analisis ragam menunjukkan bahwa perlakuan perbandingan tepung kacang hijau dan terigu berpengaruh tidak nyata $(\mathrm{P}>0,05)$ terhadap kadar air bakso analog. Tabel 2 menunjukkan bahwa seluruh perlakuan sudah menghasilkan kadar air yang sesuai dengan batas Standar Nasional Indonesia (SNI) untuk produk bakso yaitu dengan kadar air maksimum $70 \%$.

\section{Kadar Abu}

Hasil analisis ragam menunjukkan bahwa perlakuan perbandingan tepung kacang hijau dan terigu berpengaruh sangat nyata $(\mathrm{P}<0,01)$ terhadap kadar abu bakso analog. Perlakuan dengan nilai kadar abu tertinggi diperoleh pada produk P1 (Tepung Kacang Hijau $70 \mathrm{~g}$ : Terigu $30 \mathrm{~g}$ ) yaitu sebesar 2,34\%, sedangkan perlakuan dengan nilai kadar abu terendah diperoleh oleh produk P5 (Tepung Kacang Hijau $30 \mathrm{~g}$ : Terigu $70 \mathrm{~g}$ ) yaitu sebesar 1,34\%. Tabel 2 menunjukkan bahwa seluruh 
perlakuan sudah menghasilkan kadar abu yang sesuai dengan batas Standar Nasional Indonesia (SNI) untuk produk bakso yaitu dengan kadar abu maksimum 3\%. Semakin tinggi konsentrasi kacang hijau akan menghasilkan kadar abu yang semakin tinggi pada bakso analog. Purwanto et al., (2015) menyatakan bahwa kadar abu bakso dipengaruhi oleh kadar abu bahan baku yang digunakan. Hal ini sesuai dengan pernyataan Ekafitri dan Isworo (2014) yang menyatakan kadar abu pada tepung kacang hijau sebesar 3,02\%, sedangkan menurut DKBM (2005) kadar abu terigu yaitu sebesar $0,5 \%$. Hal ini juga sesuai dengan pernyataan Sukarni (1979) dalam Genisa et al., (2015) bahwa kacangkacangan selain sebagai sumber protein juga sebagai sumber mineral.

\section{Kadar Protein}

Hasil analisis ragam menunjukkan bahwa perlakuan perbandingan tepung kacang hijau dan terigu berpengaruh sangat nyata $(\mathrm{P}<0,01)$ terhadap kadar protein bakso analog. Perlakuan dengan nilai kadar protein tertinggi diperoleh pada produk P1 (Tepung Kacang Hijau $70 \mathrm{~g}$ : Terigu $30 \mathrm{~g}$ ) yaitu sebesar $10,37 \%$, sedangkan perlakuan dengan nilai kadar protein terendah yaitu pada produk P5 (Tepung Kacang Hijau 30 g : Terigu 70 g) yaitu sebesar 6,88\%. Tabel 2 menunjukkan bahwa produk P1 dan produk P2 sudah menghasilkan kadar protein yang melebihi dari batas Standar Nasional Indonesia (SNI) untuk produk bakso yaitu sebesar minimal 9,0\%, sedangkan pada produk P3, P4, dan P5 belum mencapai nilai standar pada produk bakso. Semakin tinggi konsentrasi kacang hijau maka kadar protein bakso analog akan semakin meningkat. Hal ini dikarenakan kandungan protein yang terdapat pada tepung kacang hijau lebih besar daripada kandungan protein terigu. Ekafitri dan Isworo (2014) menyatakan bahwa kandungan nutrisi pada tepung kacang hijau khususnya pada kadar protein yaitu sebesar 23,35\%, sedangkan kadar protein terigu menurut Pratama dan Nisa (2014) sebesar 11,40\%. Afrian (2002) juga menyatakan bahwa kacang-kacangan merupakan sumber protein yang mengandung protein 2-3 kali lebih besar daripada serealia.

\section{Kadar Lemak}

Hasil analisis ragam menunjukkan bahwa perlakuan perbandingan tepung kacang hijau dan terigu berpengaruh nyata $(\mathrm{P}<0,05)$ terhadap kadar lemak bakso analog. Perlakuan dengan nilai kadar lemak tertinggi diperoleh pada produk P3 (Tepung Kacang Hijau $50 \mathrm{~g}$ : Terigu $50 \mathrm{~g}$ ) yaitu sebesar 1,86\%. Sedangkan perlakuan dengan nilai kadar lemak terendah yaitu pada produk P5 (Tepung Kacang Hijau $30 \mathrm{~g}$ : Terigu $70 \mathrm{~g}$ ) yaitu sebesar $1,76 \%$. Tabel 2 menunjukkan bahwa kadar lemak seluruh perlakuan sesuai dengan batas Standar Nasional Indonesia (SNI) untuk produk bakso yaitu kadar lemak maksimum $2 \%$.

Kadar lemak bakso analog pada setiap perlakuan berkisar antara 1,76-1,86\%. Hal ini menunjukkan bahwa formulasi tepung kacang hijau dan terigu yang berbeda menghasilkan kadar lemak yang tidak jauh berbeda pada 
bakso analog. Hal ini dikarenakan oleh bahan baku yang digunakan dalam pembuatan bakso analog memiliki kadar lemak yang rendah. Mustakim (2014) melaporkan bahwa kadar lemak pada kacang hijau yaitu sebesar 1,2\%. Sedangkan menurut Damora dan Paraf dalam Genisa et al., (2015) melaporkan bahwa kandungan lemak dari terigu yaitu sebesar 0,9\%. Sari dan Widjarnako (2015) melaporkan bahwa kandungan lemak pada bakso daging sapi yang umum berada dipasaran yaitu sebesar 6,22\%. Hal ini menunjukkan bahwa bakso analog berbahan dasar tepung kacang hijau dan terigu memiliki kadar lemak yang lebih rendah yaitu berkisar $1,77-1,86 \%$.

\section{Kadar Serat Kasar}

Hasil analisis ragam menunjukkan bahwa perlakuan perbandingan tepung kacang hijau dan terigu berpengaruh sangat nyata $(\mathrm{P}<0,01)$ terhadap kadar serat kasar bakso analog. Perlakuan dengan nilai kadar serat kasar tertinggi diperoleh pada produk P1 (Tepung Kacang Hijau 70 g : Terigu 30 g) yaitu sebesar 3,04\%, sedangkan perlakuan dengan nilai kadar serat kasar terendah diperoleh oleh produk P5 (Tepung Kacang Hijau $30 \mathrm{~g}$ : Terigu $70 \mathrm{~g}$ ) yaitu sebesar 1,77\%.

Tabel 2 menunjukkan bahwa semakin tinggi penggunaan tepung kacang hijau maka semakin meningkat kadar serat kasar pada bakso analog yang dihasilkan. Kadar serat kasar bakso analog dipengaruhi oleh kadar serat kasar pada bahan baku yang digunakan. Mustakim (2014) melaporkan bahwa kandungan serat pada kacang hijau yaitu sebesar 4,1\%. Sari dan Widjarnako (2015) melaporkan bahwa kadar serat kasar bakso secara umum yang berada di pasaran yaitu 0,68\%. Hal ini menunjukkan bahwa bakso analog berbahan dasar tepung kacang hijau dan memiliki kandungan serat yang lebih tinggi yaitu berkisar $1,77-3,05 \%$.

\section{Tingkat Kekenyalan (Tekstur)}

Uji tekstur menggunakan texture analyser didapat hasil force bakso analog dapat dilihat pada Tabel 3.

Tabel 3. Nilai Force Bakso Analog dengan Perlakuan Perbandingan Tepung kacang Hijau dan Terigu.

\begin{tabular}{cc}
\hline Perlakuan (\%) & Nilai Force $(\mathrm{N})$ \\
\hline P1 (70 TKH: 30 T) & $10,17 \mathrm{a}$ \\
P2 (60 TKH: 40 T) & $9,72 \mathrm{a}$ \\
P3 (50 TKH: 50 T) & $8,22 \mathrm{~b}$ \\
P4 (40 TKH: 60 T) & $7,76 \mathrm{~b}$ \\
P5 (30 TKH: 70 T) & $6,38 \mathrm{c}$ \\
\hline
\end{tabular}

Keterangan: 1. TKH : Tepung Kacang Hijau

2. $\mathrm{T}:$ : Terigu

3. Huruf yang berbeda pada kolom yang sama menunjukkan perbedaan yang sangat nyata $(\mathrm{P}<0,01)$.

Nilai force adalah suatu tekanan yang diberikan pada suatu produk agar dapat mengetahui tingkat kekerasan produk tersebut. Berdasarkan hasil analisis ragam menunjukkan 
bahwa perlakuan perbandingan tepung kacang hijau dan terigu berpengaruh sangat nyata $(\mathrm{P}<0,01)$ terhadap tingkat kekenyalan bakso analog. Perlakuan yang menghasilkan nilai force tertinggi diperoleh pada produk $\mathrm{P} 1$ (Tepung Kacang Hijau 70 g : Terigu 30 g) yaitu sebesar $10,17 \mathrm{~N}$, sedangkan perlakuan dengan nilai force terendah diperoleh oleh produk P5 (Tepung Kacang Hijau $30 \mathrm{~g}$ : Terigu $70 \mathrm{~g}$ ) yaitu sebesar $6,38 \mathrm{~N}$.

Tabel 3 menunjukkan terjadinya penurunan nilai force bakso analog. Semakin tinggi konsentrasi kacang hijau akan menghasilkan bakso analog yang semakin tidak kenyal, hal ini dapat dilihat bahwa pada perlakuan yang mengandung konsentrasi tepung kacang hijau tertinggi menghasilkan nilai force yang tinggi. Hal ini dikarenakan pada tepung kacang hijau tidak mengandung gluten. Gluten merupakan fraksi protein yang berperan dalam pembentukan tekstur suatu produk. Pramudya et al., (2014) menyatakan bahwa gluten merupakan protein terigu yang bertekstur kenyal, sehingga semakin tinggi penggunaan terigu dalam pembuatan bakso analog akan menghasilkan tekstur yang semakin kenyal.

\section{Sifat Sensoris}

Hasil sifat sensoris kesukaan warna, aroma, rasa, tekstur dan pemerimaan keseluruhan, serta hasil sifat sensoris skoring rasa dan tekstur bakso analog dilihat pada Tabel 4.

Tabel 4. Nilai Rata-Rata Sifat Sensori Bakso Analog dengan Perlakuan Perbandingan Tepung Kacang Hijau dan Terigu

\begin{tabular}{rccccc}
\hline \multirow{2}{*}{ Perlakuan $(\%)$} & \multicolumn{4}{c}{ Parameter } \\
\cline { 2 - 6 } & Warna & Aroma & Rasa & Tekstur & Penerimaan Keseluruhan \\
\hline P1 (70 TKH: 30 T) & $1,87 \mathrm{e}$ & $3,13 \mathrm{a}$ & $1,87 \mathrm{e}$ & $1,93 \mathrm{e}$ & $2,13 \mathrm{e}$ \\
P2 (60 TKH: 40 T) & $2,33 \mathrm{~d}$ & $3,07 \mathrm{a}$ & $2,40 \mathrm{~d}$ & $2,27 \mathrm{~d}$ & $2,87 \mathrm{~d}$ \\
P3 (50 TKH: 50 T) & $3,40 \mathrm{c}$ & $3,00 \mathrm{a}$ & $3,20 \mathrm{c}$ & $2,73 \mathrm{c}$ & $3,20 \mathrm{c}$ \\
P4 (40 TKH: 60 T) & $3,87 \mathrm{~b}$ & $3,07 \mathrm{a}$ & $3,73 \mathrm{~b}$ & $3,40 \mathrm{~b}$ & $3,87 \mathrm{~b}$ \\
P5 (30 TKH: 70 T) & 4,40a & $3,00 \mathrm{a}$ & $4,13 \mathrm{a}$ & $4,27 \mathrm{a}$ & $4,40 \mathrm{a}$ \\
\hline
\end{tabular}

Keterangan: 1. TKH : Tepung Kacang Hijau

2. $\mathrm{T}$ : Terigu

3. Huruf yang berbeda pada kolom yang sama menunjukkan perbedaan yang sangat nyata $(\mathrm{P}<0,01)$. 


\section{Warna}

Warna merupakan sifat sensoris produk pangan yang dapat menarik perhatian konsumen. Berdasarkan hasil analisis ragam menunjukkan bahwa perlakuan perbandingan tepung kacang hijau dan terigu berpengaruh sangat nyata $(\mathrm{P}<0,01)$ terhadap warna bakso analog. Nilai kesukaan tertinggi terhadap warna untuk bakso analog yaitu pada produk P5 (Tepung Kacang Hijau $30 \mathrm{~g}$ : Terigu 70 g) sebesar 4,40 yaitu suka. Nilai kesukaan terendah terhadap warna untuk bakso analog yaitu pada produk P1 (Tepung Kacang Hijau $70 \mathrm{~g}$ : Terigu $30 \mathrm{~g}$ ) sebesar 1,87 yaitu tidak suka. Tingkat perbedaan warna pada setiap perlakuan bakso analog yaitu dikarenakan oleh perbedaan konsentrasi tepung kacang hijau pada setiap perlakuan. Semakin tinggi konsentrasi tepung kacang hijau maka akan menghasilkan nilai kesukaan semakin menurun. Hal ini sesuai dengan pernyataan Genisa et al., (2015) menyatakan bahwa pada bakso analog yang terbuat dari tepung kacang merah dan terigu, penambahan tepung kacang merah semakin banyak menghasilkan bakso dengan warna semakin gelap. Warna gelap tersebut disebabkan oleh kandungan klorofil yang terkandung pada kulit biji kacang hijau. Yunisuryani (2013) melaporkan bahwa kulit kacang hijau mengandung pigmen klorofil yaitu pigmen penyebab warna hijau.

\section{Aroma}

Aroma merupakan faktor yang sangat penting dalam menentukan tingkat penerimaan konsumen, namun sulit untuk didefinisikan secara obyektif. Hal ini sesuai dengan pendapat Setyaningsih 2010 dalam Elita (2016), uji sensoris pada aroma atau bau merupakan sifat sensori yang paling sulit diklasifikasikan. Berdasarkan hasil analisis ragam menunjukkan bahwa perbandingan tepung kacang hijau dan terigu tidak berpengaruh nyata $(\mathrm{P}>0,05)$ terhadap aroma bakso analog dengan nilai berkisar 3,00 - 3,13 yaitu biasa atau netral. Panelis menyatakan biasa atau netral terhadap bakso analog karena bakso analog yang dihasilkan memiliki aroma yang sama pada setiap perlakuannya yaitu seperti aroma bakso pada umumnya.

\section{Rasa}

Rasa merupakan faktor yang sangat penting pada uji sifat sensoris. Berdasarkan hasil analisis ragam menunjukkan bahwa perbandingan tepung kacang hijau dan terigu berpengaruh sangat nyata $(\mathrm{P}<0,01)$ terhadap rasa bakso analog. Nilai kesukaan terhadap rasa bakso analog tertinggi yaitu pada produk P5 (Tepung Kacang Hijau $30 \mathrm{~g}$ : Terigu 70 g) sebesar 4,13 yaitu suka. Nilai kesukaan terendah terhadap rasa untuk bakso analog yaitu pada produk P1 (Tepung Kacang Hijau $70 \mathrm{~g}$ : Terigu $30 \mathrm{~g}$ ) sebesar 1,87 yaitu tidak suka. Semakin tinggi konsentrasi tepung kacang hijau maka akan menimbulkan adanya rasa khas kacang hijau yang tajam. Hal serupa juga dilaporkan oleh Genisa et al., (2015) yang menyatakan bahwa pada pembuatan bakso analog berbahan dasar kacang merah dan terigu akan meghasilkan nilai kesukaan yang redah. Dari hasil uji skoring pada rasa bakso analog menunjukkan bahwa perbandingan konsentrasi tepung kacang hijau dan terigu 
berpengaruh sangat nyata $(\mathrm{P}<0,01)$ terhadap rasa bakso analog. Produk P1 mendapatkan nilai terbesar sebesar 4,47 yang menyatakan bahwa bakso analog memiliki rasa khas kacang hijau dan pada produk P5 mendapatkan nilai terkecil yaitu 1,60 yang menyatakan bahwa bakso analog memiliki rasa agak tidak khas kacang hijau. Produk olahan yang memiliki rasa kacang hijau terlalu kuat menyebabkan panelis tidak menyukainya.

\section{Tekstur}

Hasil analisis ragam menunjukkan bahwa perbandingan tepung kacang hijau dan terigu berpengaruh sangat nyata $(\mathrm{P}<0,01)$ terhadap parameter tekstur bakso analog. Nilai kesukaan terhadap tekstur bakso analog tertinggi yaitu pada produk P5 (Tepung Kacang Hijau 30 g : Terigu 70 g) sebesar 4,27 yaitu suka. Nilai kesukaan terendah terhadap tekstur untuk bakso analog yaitu pada produk P1 (Tepung Kacang Hijau 70 g : Terigu 30 g) sebesar 1,93 yaitu tidak suka. Perbedaan nilai kesukaan pada setiap perlakuan dikarenakan oleh perbedaan konsentrasi tepung kacang hijau dan terigu yang berbeda-beda.

Semakin tinggi konsentrasi tepung kacang hijau bakso analog akan menghasilkan nilai kesukaan semakin menurun. Hal ini dikarenakan pada perlakuan yang mengandung tepung kacang hijau tinggi akan menghasilkan tekstur bakso analog yang tidak kenyal. Hal ini ditunjukkan dengan nilai uji skoring tekstur bakso analog menunjukkan nilai ragam yang sangat berbeda nyata $(P<0,01)$ terhadap tekstur bakso analog. Produk P1 (Tepung Kacang Hijau $70 \mathrm{~g}$ : Terigu $30 \mathrm{~g}$ ) mendapatkan nilai
1,93 yang artinya agak tidak kenyal, sedangkan pada produk P5 (Tepung Kacang Hijau $30 \mathrm{~g}$ : Terigu 70 g) mendapatkan nilai 4,13 yang artinya kenyal. Hal ini sesuai dengan hasil tingkat kekenyalan bakso analog yang dianalasis menggunakan tekstur analiser yang menunjukkan bahwa semakin banyak penggunaan tepung kacang hijau dalam pembuatan bakso analog akan menghasilkan bakso yang tidak kenyal.

\section{Penerimaan Keseluruhan}

Penerimaan keseluruhan merupakan parameter yang paling terakhir untuk diamati oleh panelis. Hasil analisis ragam menunjukkan bahwa perbandingan tepung kacang hijau dan terigu berpengaruh sangat nyata $\quad(\mathrm{P}<0,01) \quad$ terhadap penerimaan keseluruhan bakso analog. Nilai kesukaan perhadap penerimaan keseluruhan bakso analog tertinggi yaitu pada produk P5 (Tepung Kacang Hijau 30 g : Terigu 70 g) sebesar 4,40 yaitu suka. Sedangkan nilai terendah terdapat pada produk P1 (Tepung Kacang Hijau 70 g : Terigu $30 \mathrm{~g}$ ) sebesar 2,73 yaitu biasa. Hal ini disebabkan karena pada perlakuan P5 bakso analog dengan rasa tidak dominan rasa kacang hijau, aroma yang disuka, warna yang disuka, dan tekstur yang kenyal. Hal ini juga dapat dikarenakan oleh panelis yang belum terbiasa mengkonsumsi bakso berbahan baku tepung kacang hijau dan terigu.

\section{KESIMPULAN DAN SARAN}

\section{Kesimpulan}

Berdasarkan hasil penelitian perbandingan tepung kacang hijau (Vigna 
radiata) dan terigu terhadap bakso analog dapat disimpulkan bahwa:

1. Perbandingan tepung kacang hijau dan terigu berpengaruh terhadap kadar protein, kadar abu, kadar lemak, kadar serat kasar, uji tingkat kenyalan (tekstur), warna, rasa, tekstur, dan penerimaan keseluruhan (uji hedonik), serta tekstur dan rasa (uji skoring).

2. Bakso analog dengan karakteristik terbaik adalah perbandingan tepung kacang hijau dan terigu sebesar $30 \mathrm{~g}: 70 \mathrm{~g}$, dengan nilai kadar air 59,66 persen, kadar abu 1,34 persen, kadar protein 6,88 persen, kadar lemak 1,77 persen, kadar serat kasar 1,77 persen, tingkat kekenyalan 6,38 N, warna suka, aroma biasa (netral), tekstur suka dengan karakteristik kenyal, rasa suka dengan rasa agak tidak khas kacang hijau dan penerimaan suka.

\section{Saran}

1. Untuk menghasilkan bakso analog terbaik disarankan menggunakan perbandingan tepung kacang hijau $30 \mathrm{~g}$ dan terigu $70 \mathrm{~g}$.

2. Perlu dilakukan penelitian lebih lanjut mengenai penambahan sumber protein yang lain untuk meningkatkan kadar protein bakso analog sehingga memenuhi nilai standar SNI yang ditetapkan.

\section{DAFTAR PUSTAKA}

Afrian., R., N. 2002. Mempelajari Sifat Kimia, Mutu Gizi, Sifat Fisik dan Organoleptik Bubur Kacang Hijau Instan. Skripsi S1. Fakultas Pertanian IPB,Bogor.

Anonimus. 2006. Bakso Daging, Minuman Sari Lidah Buaya, Roti Manis, Menu
Sehat Bagi Manula, Sari Buah. Jurnal Tekno Pangan dan Agroindustri. 1(6).

Damayanti., M. C., Cahyana, dan Ridawati. 2012. Pengaruh Penggunaan Bahan Pengikat (pati sagu aren dan pati garut) terhadap Daya Terima Konsumen Bakso Ayam. Fakultas Teknik Universitas Negeri Jakarta, Jakarta.

Direktorat Gizi. 2005. Daftar Komposisi Bahan Makanan (DKBM). Persatuan Ahli Gizi Indonesia (Persagi), Jakarta.

Ekafitri, R dan R. Isworo. 2014. Pemanfaatan Kacang-Kacangan sebagai Bahan Baku Sumber Protein untuk Pangan Darurat. Fakultas Pertanian Universitas Sebelas Maret, Surakarta.

Genisa., J., N. K. Sukendar, J. Langkong dan N. Abdullah. 2015. Analog Bakso Sehat dari Protein Kacang Merah (Phaseolus vulgaris L). Jurnal AgriTechno. 8(1): 1-9.

Kurniawan, A. B., A. N. Al-Baarri, dan Kusrahayu. 2012. Kadar Serat Kasar, Daya Ikat Air, dan Rendemen Bakso Ayam Dengan Penambahan Karaginan. Jurnal Aplikasi Teknologi Pangan. 1(2).

Kusnadi, D. C V. P., Bintoro, dan A. N. AlBaarri. 2012. Daya Ikat Air, Tingkat Kekenyalan dan Kadar Protein pada Bakso Kombinasi Daging Sapi dan Daging Kelinci. Jurnal Aplikasi Teknologi Pangan. 1(2).

Mustakim, M. 2014. Budidaya Kacang Hijau Secara Intensif. Pustaka Baru Press, Yogyakartar

Pramudya., M. R., E. Julianti., dan L. M. Lubis. 2014. Pengembangan Produk Bakso Kedelai (Soyballs) dengan Penambahan Gluten serta Pati dari Ubi Kayu, Ubi Jalar, Jagung dan Kentang. Jurnal Rekayasa Pangan dan Pertanian. 2(2): 84-95.

Pratama., I. A., dan F. C. Nisa. 2014. Formulasi Mie Kering dengan Subtitusi Tepung Kimpul (Xanthosoma sagitrifolium) dan Penambahan Tepung Kacang Hijau (Phaseolus radiates L). Jurnal Pangan dan Agroindustri. 2(4): 101-112.

Purwanto, P., A. Ali, dan N. Herawati. 2015. Kajian Mutu Gizi Bakso Berbasis Daging Sapi dan Jamur Merang 
(Volvariella volvaceae). Jurnal SAGU. 14(2): 1-8.

Rakhmawati, E. D. 2011. Pengaruh Penambahan Tepung Kecambah Kacang HIjau (Phaseolus radiates L.) Terhadap Kualitas Kimia dan Tingkat Kesukaan Bakso Daging Ayam Broiler. Skripsi S1. Fakultas Pertanian Universitas Sebelas Maret, Surakarta.

Rusiani, Y. 2016. Pembuatan Isolat Protein Kacang Merah (Phaseolus vulgaris $\mathrm{L}$ ) dengan Variasi Jenis dan Konsentrasi Asam. Skripsi S1. Tidak Dipublikasikan. Fakultas Teknik Universitas Pasundan, Bandung.

Sari, H. A. dan S. B. Widjanarko. 2015. Karakteristik Kimia Bakso Sapi (Kajian Proporsi Tapioka: Tepung Porang dan Penambahan NaCl. Jurnal Pangan dan Agroindustri 3(3): 784-79.

Situngkir, D. Y. 2010. Studi Pengaruh Tepung Komposit Biji-Bijian dan Konsentrasi Penstabil Terhadap Mutu Makanan Pendamping ASI-Biskuit.Skripsi S1. Universitas Sumatera Utara, Sumatera Utara.

Soekarto, S. T. 1985. Penilaian Organoleptik untuk Industri Pangan dan Pertanian. Bharata Karya Aksara, Jakarta.

Steel, R. G. D dan J. H. Torrrie. 1993. Prinsip dan Prosedur Statistik Penerjemahan Bangbang Sumantri. PT. Gramedia Pustaka Utama, Jakarta.

Sudarmadji, S., B. Haryono, dan Suhardi. 1997. Prosedur Analisa untuk Bahan Makanan dan Pertanian. Liberty, Yogyakarta.

Yunisuryani. 2013. Tepung Legum (Kacang Hijau dan Kacang Kedelai). https://www.google.co.id/amp/s/yunis uryani2013.wordpress.com. Diakses pada tanggal 02 Agustus 2017. 